\title{
Can Cape Town's unique biodiversity be saved? Balancing conservation imperatives and development needs
}

\author{
$\underline{\text { Patricia M. Holmes }}^{1}, \underline{\text { Anthony G. Rebelo }}^{2}, \underline{\text { Clifford Dorse }}^{1}$, and Julia Wood $^{1}$
}

\begin{abstract}
Cape Town is an urban hotspot within the Cape Floristic Region global biodiversity hotspot. This city of 2,460 $\mathrm{km}^{2}$ encompasses four local centers of fynbos plant endemism, 19 national terrestrial vegetation types (six endemic to the city), wetland and coastal ecosystems, and 190 endemic plant species. Biodiversity in the lowlands is under threat of extinction as a result of habitat loss to agriculture, urban development, mining, and degradation by invasive alien plants. Cape Town's population is 3.7 million, increasing by an estimated 55,000 people/yr, which puts pressure on biodiversity remnants for development. South Africa is a signatory to international instruments to reduce biodiversity loss and has a good legislative and policy framework to conserve biodiversity, yet implementation actions are slow, with limited national and provincial support to conserve Cape Town's unique and irreplaceable biodiversity. The lack-of-action problem is two-fold: national government is slow to implement the policies developed to realize the international instruments it has signed, with conservation initiatives inadequately funded; and local governments are not yet recognized as important implementation partners. A further problem is created by conflicting policies such as the national housing policy that contributes to urban sprawl and loss of critical biodiversity areas. The City's Biodiversity Management Branch, with partners, is making some headway at implementation, but stronger political commitment is needed at all levels of government. Our objective is to improve the status and management of biodiversity in existing conservation areas through the statutory proclamation process and management effectiveness monitoring, respectively, and to secure priority areas of the BioNet, Cape Town's systematic biodiversity plan. The most important tools for the latter are incorporating the BioNet plan into City spatial plans; communication, education, and public awareness; negotiating appropriate management of public land; and conservation stewardship on private land. The timeframe to save Cape Town's biodiversity is short, and it is unlikely that full success will be achieved without national or international funding and political will at all levels of government.
\end{abstract}

Key Words: biodiversity conservation policy; Cape Floristic Region; habitat loss; implementation; South Africa; urban biodiversity hotspot

\section{INTRODUCTION}

In an extensively urbanizing world, the impact of cities on biodiversity is increasingly considered an important conservation issue, particularly in global biodiversity hotspots. We use Cape Town, in the developing nation of South Africa, to assess the effectiveness of policy and implementation measures in halting biodiversity loss. Rapid growth of Cape Town is eclipsing critical biodiversity areas and the ecosystem services they deliver.

Cape Town is the economic hub of the Western Cape and has the highest per capita population growth rate in South Africa (Boraine et al. 2006; K. Small, personal communication), contributing to the Cape Floristic Region (CFR) having the second-highest population growth rate among Mediterranean regions, after Chile (Underwood et al. 2009). In 2010, the city's population was estimated at 3.7 million, with an annual increase of 55,000 people, mainly through immigration from other provinces (City of Cape Town, unpublished data). Urban development, agriculture, and natural remnants cover $26 \%$, $35 \%$, and $39 \%$, respectively, of the $2,460 \mathrm{~km}^{2}$ city area.
Cape Town is located in the CFR, which is the smallest, and for its size, richest of the world's six floral kingdoms (Cowling et al. 1992). The CFR is a World Heritage Site and one of 25 global biodiversity hotspots (Myers et al. 2000), being a species-rich area exhibiting high levels of endemism and threatened biodiversity. The natural environment is one of Cape Town's most valuable assets and includes the majestic Table Mountain and Cape Peninsula (now a national park), 17 nature reserves, and a $307-\mathrm{km}$ coastline (Fig. 1).

We summarize the biodiversity conservation policy framework in South Africa and how it influences practices at the municipal level in terms of biodiversity assessment and implementation. We then discuss the policy-practice divide and the challenges of balancing development needs and biodiversity conservation imperatives. We review the status and threats to Cape Town's terrestrial and fresh water biodiversity and discuss why conserving it is important. We conclude by reporting on several proactive conservation initiatives currently underway, addressing our leading question of whether Cape Town's unique biodiversity can be saved. 
Fig. 1. Location of Cape Town in relation to the fynbos biome (grey) and neighboring biomes in South Africa. The fynbos biome largely delimits the extent of the Cape Floristic Region (dark boundary line).

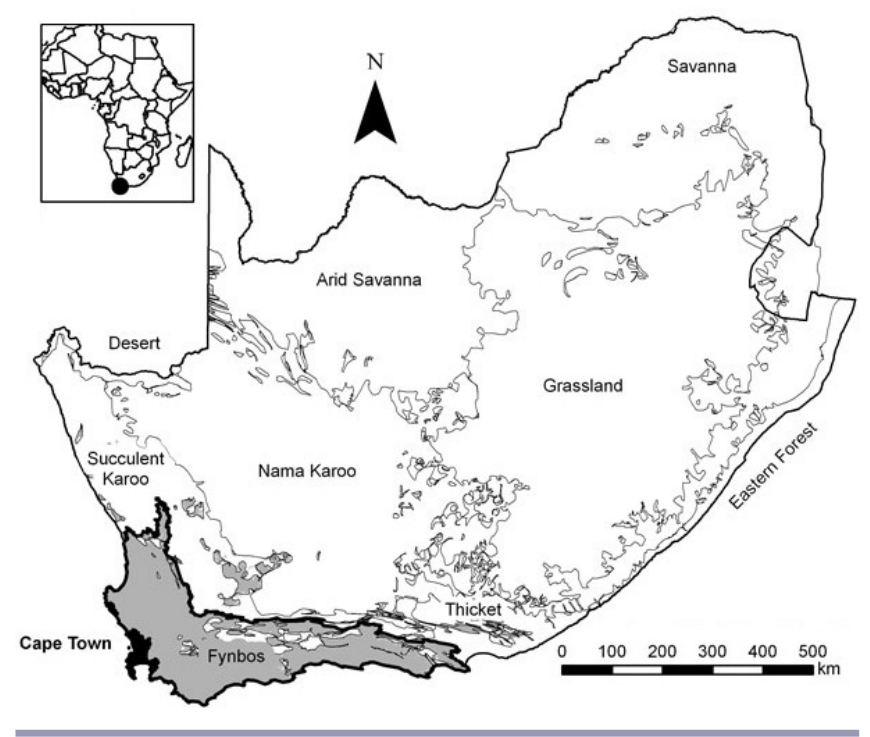

\section{BIODIVERSITY CONSERVATION POLICY AND IMPLEMENTATION}

\section{South African conservation policy and legislation}

South Africa is a signatory to a number of international instruments that are designed to guide the behavior of states, for example: the World Charter for Nature (1982), the Rio Declaration on Environment and Development (1992), and the Convention on Biological Diversity (CBD; Rio de Janeiro 1992, Nagoya 2010). Although the CBD is a nonbinding instrument, its tenets are embodied in South African legislation: the overarching legislative tool being the South African Constitution (1996), which sets out basic environmental rights and assigns powers and functions. In keeping with the Constitutional provisions, the National Environmental Management Act (NEMA) 107 of 1998 (Government of South Africa 1998) provides the framework that sets out principles and procedures for environmental management, assessment, and governance. Two subsequent acts are central to biodiversity conservation: the Protected Areas Act 57 of 2003 (Government of South Africa 2003) and the Biodiversity Act 10 of 2004 (Government of South Africa 2004). Five key policy tools are legislated in the Biodiversity Act:

1. The National Biodiversity Strategy and Action Plan (NBSAP), 2005: The NBSAP was developed in response to the $\mathrm{CBD}$ and national needs. It provides a comprehensive framework and long-term plan of action for the conservation and sustainable use of South Africa's biodiversity;

2. The National Spatial Biodiversity Assessment (NSBA; Rouget et al. 2004): The NSBA focuses on ecosystems, primarily the national vegetation types (Mucina et al. 2006), their threat status and protection levels, and provides a national context for the development of provincial and local spatial biodiversity assessments and plans. This assessment has been updated (Government of South Africa 2009);

3. The National Protected Area Expansion Strategy (NPAES), 2008: This has been developed to achieve costeffective protected area expansion that enhances ecological sustainability and resilience to climate change, with a focus on expanding existing protected areas (Government of South Africa 2010);

4. The National Biodiversity Framework (NBF), 2008: The NBF sets out 33 priority actions, some of which are key to conservation implementation in biodiversity hotspots such as Cape Town; for example, finalize the 20-yr NPAES, underpinned by national biodiversity targets (No. 29); implement the NPAES strategy (No. 30); and establish and strengthen provincial stewardship programs (No. 31);

5. Bioregions and Bioregional Plan: A bioregion may be determined by the national or provincial environment minister, who also approves the bioregional plan, which includes a systematic biodiversity plan and measures for effective management.

\section{How national policy and legislation influence practice in} Cape Town

Although all tiers of government are implicated in NEMA under section 28 "duty of care," the biodiversity legislation is primarily implemented at national and provincial levels. The first four policy tools described above operate at a national level, although biodiversity assessments and plans are guided by these policies at all levels of government.

At the municipal level, the leading strategic tool for management and implementation of projects is the Integrated Development Plan (IDP), essentially the business plan for the city. However, none of the seven focus areas of the IDP includes management or conservation of the natural environment as a key element. The IDP alludes to new tourism development opportunities in the False Bay Coastal Park and Blaauwberg Conservation Area, again emphasizing development rather than conservation. There is no further inclusion of the natural environment in the details of the IDP and, therefore, no allocation of budget for conservation projects. The City IDP implements national and equivalent provincial policies on growth and development but does not 
engage directly with biodiversity legislation and policy, interpreting the latter as a provincial mandate. This is unfortunate because municipalities are responsible for spatial and land-use planning, which can greatly influence biodiversity conservation potential across municipal areas. The only way that the conservation sector can influence the IDP, other than by participating in the public commenting process, is to link conservation to municipal goals. For example, the current City administration has among its five goals "an opportunity city." Biodiversity conservation can be linked to this directly via natural resource management job creation and skills development training.

The strongest policy tool that the biodiversity sector can influence at the municipal level, after the IDP, is the Spatial Development Framework (SDF). Because the systematic biodiversity plan for the city (BioNet; Fig. 2) is aligned to national legislation and policy, there is a strong basis from which to argue its recognition in the SDF. In this regard, there has been relative success, especially outside the urban edge. However, there remain some conflicts between biodiversity and proposed new development areas in the SDF that will only be resolved reactively through the provincial environmental impact assessment process. In municipalities that lack dedicated biodiversity staff, spatial planners are reluctant to plan for conservation networks (e.g., Sandström et al. 2006).

In 2010, the City initiated the process to publish a Bioregional Plan (policy tool 5, above), which will result in some legal status for the BioNet plan, although this cannot be in conflict with the SDF. The city has been approved as a "Bioregion", and the provincial environment minister has also approved the bioregional planning process. The City is collaborating with the national and provincial biodiversity conservation sectors as well as stakeholders from other key municipal and government departments and organizations. This is a good example of cross-scale governance interaction on mainstream national biodiversity conservation policy at the local level.

\section{The policy-practice divide}

Whereas South Africa is a signatory to various international instruments and has developed good biodiversity legislation and policy that embody those principles and the best available science (Ryder et al. 2010), conservation action on the ground is slow, indicating a policy-practice divide (Gibbons et al. 2008). Nationally, only $6.5 \%$ of the land surface is conserved in protected areas (Government of South Africa 2010), whereas the latest target adopted by the CBD 10 in Nagoya (the 2010 Aichi Target) is 17\%. This conservation estate is also highly skewed and not representative of national biodiversity patterns (Cadman et al. 2010). Although Cape Town and other areas of the CFR lowlands should be national conservation priorities, no funding from national or provincial governments is earmarked for implementation in the city. For instance, in the latest ecosystem assessment, the city's endemic Cape Flats Sand Fynbos has been elevated to the position of "most unlucky" threatened ecosystem (Driver personal communication), yet there are no plans at the national or provincial level to increase conservation protection for this vegetation type.

Fig. 2. Map of the BioNet plan, a systematic conservation plan for the city of Cape Town. CBA = critical biodiversity areas; $\mathrm{CESA}=$ critical ecological support areas .

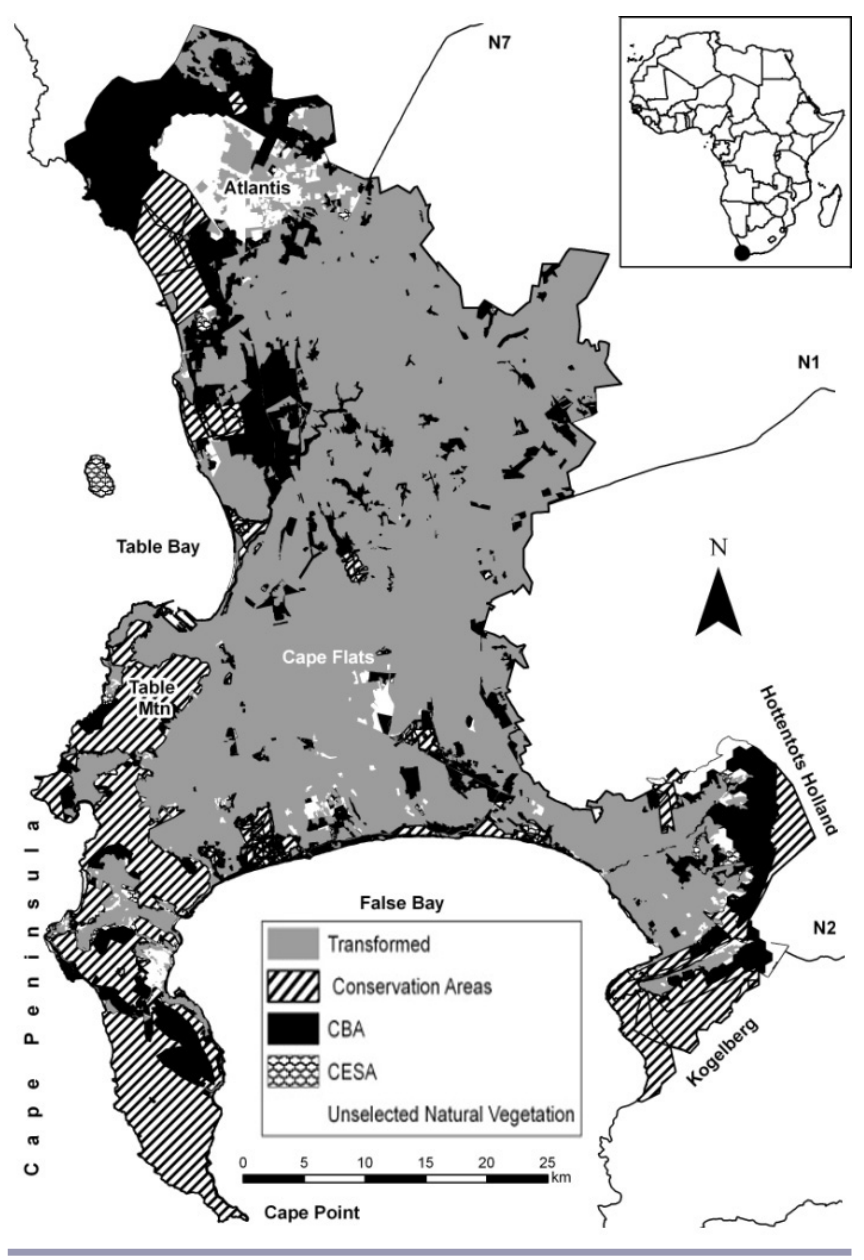

Part of the problem may lie in the NBF, which fails to recognize the role of local government in biodiversity conservation implementation: all priority actions are allocated to either national or provincial organizations or government departments. Because spatial planning is a municipal mandate and developments occur at this level, either local government should be included as a conservation implementation partner or else the provincial conservation agencies should be considerably strengthened to support implementation in municipalities. Internationally, the importance of local government was acknowledged recently by the Conference of the Parties at the CBD 10 in Nagoya: the Plan of Action was endorsed whereby national governments now have an 
obligation to consider and involve other levels of government in their national biodiversity strategies and action plans.

A further problem lies with the NPAES, which does not prioritize the most threatened ecosystems but rather aims to achieve cost-effective reserve expansion based on existing national parks with the aim of enhancing ecological sustainability and resilience to climate change. The focus is on rural or remote areas where land is cheapest. There is not a single reserve expansion proposed for Cape Town, and only one is planned for the entire lowlands of the CFR biodiversity hotspot.

At the provincial level, the Protected Area Expansion Strategy includes one area that overlaps in the rural north of the city to connect an inland provincial nature reserve to the coast. This includes parts of the Cape West Coast Biosphere Reserve and the BioNet plan and hence is a collaborative initiative. However, there is no funding to implement this strategy, and despite the NBF strategic objective to "strengthen provincial stewardship programs," national government has cut funding to the conservation protection sector, affecting this costeffective implementation tool (Debbie Jewitt, personal communication).

National government has developed the required policy tools but has been slow to implement them. Thus, conservation initiatives are not adequately funded, with insufficient allocation to implement them at provincial and local levels. In addition, there is a lack of process to create dialog among public sector agencies responsible for implementation or to produce binding commitments (Roux et al. 2008). South Arica is not alone in failing to meet international conservation obligations. For example, in Greece, failure to conserve its European Natura sites results partly from a lack of appropriate national policies because of political interference and conflicting interests as well as under-resourcing for management (Apostolopoulou and Pantis 2009).

There are some conflicting policies at all levels of government that may hamper conservation actions (Roux et al. 2008). Both the provincial and City SDF propound densification within the urban edge to counter urban sprawl. Broadly, this is a sound planning and environmental policy that is compatible with biodiversity conservation. However, conflicts arise because Cape Town has unique biodiversity areas inside the urban edge, e.g., $13 \%$ of the lowlands inside the urban edge are earmarked by the BioNet plan for conservation. These are further exacerbated by the high demand for housing (currently 400,000 units), a large proportion of which has to be funded by grants under the National Housing Board policy that are insufficient to build denser (e.g., double story) developments.

\section{THE STATUS OF CAPE TOWN'S UNIQUE BIODIVERSITY}

\section{A description of Cape Town's biodiversity}

The CFR covers only $4 \%$ of South Africa yet is considered a global biodiversity hotspot owing to the high richness (9000 taxa) and endemism (70\%) of the flora and the imminent threat of extinction facing the biota (Cowling et al. 1992, Myers et al. 2000). Many CFR vegetation types located outside of the mountain catchment areas are poorly conserved and highly transformed by agriculture, urbanization, and invasive alien vegetation (Rebelo 1992). This is reflected in the 2004 NSBA in which almost half $(46 \%)$ of the vegetation types were considered threatened by habitat transformation (Rouget et al. 2004, Driver et al. 2005). In the latest ecosystem assessment, 21 of the 23 national Critically Endangered vegetation types occur in the CFR (Government of South Africa 2009). Cape Town's biodiversity reflects that of the CFR as a whole, but more acutely: Although the city encompasses only $3 \%$ of the CFR, it has $16 \%$ of the vegetation types (Rebelo et al. 2006) and one-third of the plant species represented (Rebelo et al. 2011). The high floral richness, diversity, and endemism of the Cape Peninsula are well documented (Simmons and Cowling 1996, Helme and Trinder-Smith 2006). In addition, the city lowlands support a different flora that is also rich in local endemics and threatened species (Rebelo et al. 2006, 2011).

Cape Town is also rich in freshwater and marine ecosystems. Many small rivers traverse the city, and much of the Cape Flats historically comprised a myriad of small, shallow lakes (vleis), seasonal wetlands, and vernal pools, many of which were interconnected (Brown and Magoba 2009). Today, a large proportion of the lowland wetland ecosystem has been modified or lost.

At the species level, Cape Town is rich in vertebrate fauna as well as flora (Table 1), although several of the charismatic larger mammals such as black rhinoceros were hunted to local extinction by 1700 (Rebelo 1992). The city has at least 190 endemic plants and two endemic amphibians (Table 1). IUCN Red List Threatened plants are over-represented in the city at 319 , or $12 \%$ of the South African total in only $0.1 \%$ of its area. In addition, 13 plants are globally extinct or extinct in the wild (57\% of the South African total; Raimondo et al. 2009). Cape Town's threatened plant figures are higher than those for most countries in the world and, to our knowledge, exceed those listed for any other city. The invertebrate fauna is less well known, but there is evidence of high richness and endemism reflecting that of the flora. For example, on the Cape Peninsula alone, endemic species include 21 spiders and scorpions, 21 millipedes and centipedes, 18 crustaceans, 16 beetles, and 12 earthworms (Picker and Samways 1996). 
Table 1. Richness of biodiversity features in Cape Town, Republic of South Africa (RSA). $\dagger$

\begin{tabular}{|c|c|c|c|c|c|c|c|c|}
\hline $\begin{array}{l}\text { Biodiversity } \\
\text { feature }\end{array}$ & $\begin{array}{c}\text { Total } \\
\text { indigenous in } \\
\text { city }\end{array}$ & Endemic to city & $\begin{array}{l}\text { Threatened/ } \\
\text { Red List: }\end{array}$ & $\begin{array}{l}\text { Locally extinct } \\
\text { in city }\end{array}$ & Naturalized & $\begin{array}{c}\text { Endemic to } \\
\text { RSA }\end{array}$ & $\%$ RSA in city & $\begin{array}{c}\% \text { RSA } \\
\text { Threatened in } \\
\text { city }\end{array}$ \\
\hline Vegetation type & 19 & 6 & 16 & $0 \S$ & N/A & 19 & 5 & 20 \\
\hline Plants & $>3350$ & $>190$ & 450 & $>49$ & $>450$ & $>2800$ & 17 & 17 \\
\hline Mammals! & 83 & 0 & 24 & 8 & 7 & 16 & 28 & 16 \\
\hline Birds & 367 & 0 & $22 \pi$ & 9 & 10 & 16 & 44 & 21 \\
\hline Reptiles & 60 & 0 & 8 & 2 & 6 & 28 & 14 & 8 \\
\hline Amphibians & 27 & 2 & 10 & 0 & 3 & 25 & 32 & 30 \\
\hline $\begin{array}{l}\text { Freshwater } \\
\text { fish\# }\end{array}$ & 8 & 0 & 5 & 1 & 12 & 7 & 6 & 10 \\
\hline
\end{tabular}

$\dagger$ Modified from Rebelo et al. (2011). Biodiversity features include vegetation types covering $>1 \mathrm{~km}^{2}$ (Anonymous 2009 ; A. Driver, personal communication), higher plants (Raimondo et al. 2009), and vertebrates, including mammals (Minter et al. 2004), birds (Barnes 2000), reptiles (Branch 1998; currently under revision, M. Burger, personal communication), amphibians (Minter et al. 2004), and fish (Impson 2007, Tweddle et al. 2009; currently under revision).

†Extinct, Threatened (CR, EN, and VU), Near Threatened, and Data Deficient species, or threatened ecosystems for vegetation types.

$\S$ A small area of CR Swartland Alluvium Renosterveld $\left(<1 \mathrm{~km}^{2}\right)$ used to occur in the city but has been destroyed.

|Excluding vagrant and pelagic species.

IIIncluding locally extinct species.

\#Under revision, with Galaxius zebratus and Sandelia capensis to be split into several threatened species, two and one of which may be largely endemic to and threatened in the City, respectively (D. Tweddle, personal communication).

\section{Systematic biodiversity assessment}

The City has been a leader among South African municipalities in using systematic biodiversity assessment (Margules and Pressey 2000) to determine the minimum representative sample of biodiversity to conserve. The first comprehensive systematic biodiversity plan, the BioNet plan, was produced in 2004 and has been updated regularly to incorporate the latest information and to align with national requirements (Rebelo et al. 2011). A wetland mapping and prioritization project was completed in 2009 and the results incorporated into the BioNet plan (K. Snaddon, personal communication).

Today, $61 \%$ of the city's natural vegetation is transformed, with disproportionately high transformation in the lowlands, as a result of agriculture and urban sprawl (Table 2). Approximately $90 \%$ of the remaining natural remnants, representing $35.1 \%$ of the total city area, are selected in the BioNet plan either as existing conservation areas or planned critical biodiversity areas (CBA) and critical ecological support areas (CESA; Fig. 2). CBAs are defined as terrestrial and aquatic features of the landscape that are critical for conserving biodiversity and maintaining ecosystem functioning (Department of Environmental Affairs and Tourism 2007). CBAs must be determined through a systematic biodiversity plan in which quantitative targets or goals are established. These targets reflect the best scientific understanding of how much of each feature (e.g., vegetation type, wetland type, rare species occurrence, or population) is required not only to represent the full array of natural diversity in an area, but also to ensure it persists into the future. CESAs are supporting zones required to prevent the degradation of conservation areas and CBAs (Maree and Vromans 2010).

Not all of the CBAs are in good habitat condition, especially in the lowlands (Table 2); $28 \%$ of the lowland CBAs are in poor condition and need ecological restoration compared to $1 \%$ in the uplands. Twelve of the 19 national vegetation types in the city have sufficient remnant area remaining to meet minimum national biodiversity targets, but only 8 are sufficiently represented in conservation areas (Rebelo et al. 2011). Some of these conservation areas are not safe in perpetuity and require proclamation under the Protected Areas Act. Only two of the city's six endemic vegetation types are adequately conserved: Peninsula Sandstone and Granite Fynbos, in the Table Mountain National Park, although the latter will attain the minimum national target only once pine plantations are restored to fynbos. Three city endemic vegetation types, i.e., Peninsula Shale Renosterveld, Cape Flats Sand Fynbos, and Lourensford Alluvium Fynbos, have insufficient habitat left to meet minimum national targets. Thus, all remaining viable remnants are a conservation priority.

The city represents a low-choice planning domain for systematic biodiversity assessment (i.e., there are few alternative planning units to meet certain biodiversity criteria 
Table 2. Condition of mainland BioNet remnants and other city areas in relation to the urban edge.

\begin{tabular}{|c|c|c|c|c|c|c|c|}
\hline \multirow[b]{2}{*}{$\underline{\text { Site condition }}$} & \multicolumn{3}{|c|}{ Upland $\dagger$} & \multicolumn{3}{|c|}{ Lowland $\$$} & \multirow[b]{2}{*}{ Total (ha } \\
\hline & Inside $(\%)$ & Outside $(\%)$ & Subtotal (ha) & Inside $(\%)$ & Outside $(\%)$ & Subtotal (ha) & \\
\hline Natural, high quality§ & 0 & 100 & 42,423 & 18 & 82 & 24,048 & 66,471 \\
\hline $\begin{array}{l}\text { Natural, medium } \\
\text { quality! }\end{array}$ & 9 & 91 & 1240 & 47 & 53 & 10,808 & 12,048 \\
\hline Natural, low qualityII & 10 & 90 & 881 & 33 & 67 & 6650 & 7531 \\
\hline Natural, unselected\# & 11 & 89 & 2621 & 27 & 73 & 7225 & 9846 \\
\hline Total natural & 1 & 99 & 47,165 & 28 & 72 & 48,731 & 95,896 \\
\hline Transformed $\dagger \dagger$ & 68 & 32 & 10,999 & 54 & 46 & 138,505 & \\
\hline
\end{tabular}

$\dagger$ Associated with mountain chains.

¥Cape Flats and West Coast forelands, incorporating the low shale and granite hills.

$\S$ Sites retain biodiversity structure, diversity, and function, but may support some invasive alien vegetation.

¡Sites have lost some structural components and diversity.

IISites have lost structure and a high proportion of diversity, but soils are intact and vegetation is considered restorable.

\#Natural areas not included in the Biodiversity Network.

$\dagger \dagger$ Developed or cultivated areas that are considered nonrestorable.

or targets), as most extant biodiversity features are threatened, with high levels of irreplaceability (Rebelo et al. 2011). Thus, further refinements to the analysis are unlikely to yield significantly different results. It is more important to focus efforts in developing an implementation strategy involving key stakeholders (Knight et al. 2006, 2008). Relative to other municipalities, the City is well-placed to tackle implementation, as it has a Biodiversity Management Branch (BMB). Whereas it is important to have a scientifically sound systematic biodiversity assessment to support the implementation strategy, the City embraces opportunism in achieving action (Knight and Cowling 2007, Cowling et al. 2009). Various implementation approaches are being explored, with emphasis on aligning priorities with human and social capital to mobilize support for conservation action.

\section{Threats to Cape Town's biodiversity}

The primary driver of biodiversity loss in Cape Town is habitat destruction. There are several parallels between Cape Town and other Mediterranean biome regions. For example, habitat transformation is associated with increasing human population densities concentrated in lowland areas, with recent transformation associated more with urbanization than agricultural expansion; threatened species richness has a significant positive correlation with human population density (Underwood et al. 2009). A global synthesis of plant extinction rates in urban areas indicates the importance of both historical development and the current proportion of native vegetation remaining (Hahs et al. 2009). In cities such as Cape Town, with a history exceeding $200 \mathrm{yr}$, it is important to preserve native vegetation in urban areas.

Urbanization of Cape Town is driven by high population growth. Lowland CBAs within the urban edge are particularly vulnerable, both to formal development of an estimated 6.5 $\mathrm{km}^{2} / \mathrm{yr}$ (Rebelo et al. 2011) and informal settlement (223 sites recorded at present; City of Cape Town, unpublished data). At current projections, all unprotected natural remnants will be developed by 2020 , foreclosing any future conservation action.

Invasive alien species, mainly plants, are another primary driver of biodiversity loss (Richardson and van Wilgen 2004) and are the greatest threat to biodiversity by area after habitat transformation (Raimondo et al. 2009). In common with many port cities, Cape Town has a high level of naturalized alien species in all taxonomic groups (Table 1). Many of these plant species are invasive and directly threaten native biodiversity, whereas only a few alien animals have ecosystem-level effects.

Secondary drivers of biodiversity loss include habitat fragmentation effects (Pauw and Louw 2012, unsustainable harvesting (Petersen et al. 2012), and loss of keystone species (e.g., megaherbivores in some ecosystems; Rebelo et al. 2011), with global climate change being a further potential threat (Midgley et al. 2002).

Appropriate ecological management can counter some of the secondary drivers of biodiversity loss, whereas lack of management results in habitat deterioration and biodiversity loss. For example, on the Cape Flats, a lack of management leads to invasion and dominance of natural remnants by alien trees such as the Australian wattle species Acacia saligna. Alien trees provide cover for criminal activities and land invasion, creating the perception among surrounding communities that natural open space is a liability (naming such areas "The Bush of Evil"). Thus, lack of open-space 
management can lead to negative perceptions of biodiversity conservation initiatives. Management capacity is thus critical for all natural remnants. A less tangible effect of urbanization is the threat of biotic homogenization resulting from human modifications to landscapes (McKinney 2006). To counter this effect, it is important that natural areas are managed and local indigenous species, subspecies, and ecotypes promoted through restoration programs.

\section{The rationale for conserving Cape Town's biodiversity}

It is clear that Cape Town is very rich in biodiversity at both species and ecosystem levels and may be considered a local hotspot within the CFR global biodiversity hotspot (Wood et al. 1994). Indeed, the Cape Flats, including some neighboring lowland areas bordering the city, are today home to the greatest concentration of endangered and critically endangered plants in South Africa and possibly the world (Raimondo et al. 2009). The fact that a high proportion of the city's biodiversity is unique or threatened should be sufficient motivation to conserve it. At a global scale, Mediterranean climate regions and biodiversity hotspots are conservation priorities (Myers et al. 2000, Underwood et al. 2009).

However, relying on biodiversity importance or prioritization to achieve conservation action generally has failed elsewhere (Knight et al. 2008). It has to be acknowledged that conservation implementation is a social process that is informed by science (Knight et al. 2011). Successful implementation means exploring economic, social, and human dimensions and engaging with key stakeholders such as local politicians, government officials from nonbiodiversity sectors, land owners, and local communities to promote knowledge interfacing and enable conservation action (Knight et al. 2006, Roux et al. 2006; T. Layne and C. Fabricius, unpublished manuscript). Given the above experiences, it is important to present other key arguments for conserving biodiversity, which include the provision of ecosystem goods and services, job creation in the environmental and tourism sectors, and the building of a resilient, sustainable city.

The city's natural assets, including the land, coast, biota, water bodies, and atmosphere, produce a flow of goods and services that have value for residents and visitors amounting to $\$ 510$ million/yr (range: \$250-760 million/yr, USD), although not all ecosystem goods and services can be costed (De Wit et al. 2009). Other studies in the CFR also indicate the high value of biodiversity to the region's economy (e.g., Turpie et al. 2003). Well-functioning natural ecosystems will help to buffer the city from extreme weather events, which are predicted to increase under climate change (A. Cartwright, personal communication), as well as providing green lungs and quality natural open space. The latter assets are important in supporting a healthy and happy population (Chivian and Bernstein 2008, Ashwell 2010).
Communication, education, and public awareness are critical in gaining support for biodiversity conservation, as there is a strong socioeconomic basis for much greater investment in the environmental resource management field. Creating more jobs to manage the natural areas would both conserve biodiversity and secure the flow of ecosystem services into the future. This is a key focus area; in the 2010-2011 financial year, the City's BMB created 44,000 person-days of temporary employment, accompanied by skills development. Improved management is essential to retain resilience in the face of global climate change and ongoing urban development pressures and to build a sustainable city. The Indonesian government has ratified a law to ensure that cities retain a minimum area of $30 \%$ green open space to provide for these important ecological services (Arifin and Nakagoshi 2011). Good management of natural open spaces will unlock indirect job opportunities in the tourism sector and enable potential economic spin-offs and social well-being. Gill et al. (2009) argue that the social value of natural open spaces in urban areas should be the primary motivation for conservation.

\section{CONSERVATION IMPLEMENTATION INITIATIVES IN CAPE TOWN}

It is difficult to predict what an effective implementation process will comprise, but a transdisciplinary approach is recommended (Knight et al. 2011). In Sweden, where biodiversity conservation is an agreed value among the population and scientific knowledge is integrated into the political process, implementation may still be hampered by key institutional gaps (Angelstam et al. 2003). The City of Cape Town's BMB has among its strategic objectives improved ecological and protection status of existing conservation areas and the securing of other BioNet sites, and multiple tools are used to achieve the latter. Five BioNet plan areas are prioritized for implementation action, as outlined in the Local Biodiversity Implementation Plan. However, should conservation opportunities outside these areas become available through other processes, these are also considered.

\section{Improved ecological and protection status of existing conservation areas}

The City manages 30 conservation areas (16 Contract Nature Reserves, 14 Biodiversity Agreements), yet many of these sites are not secure in perpetuity. In addition, being relatively small areas with large edge effects and altered ecological processes, the biodiversity will not persist over the long term unless the sites are managed effectively. A process to proclaim existing conservation areas under the Protected Areas Act is underway. The requirements include a reserve management plan and a public participation process to review the proposed reserve boundaries and plans. These proposals have been approved by City Council, further creating awareness of the importance of Cape Town's biodiversity. The internationally recognized Management Effectiveness Tracking Tool system 
is being implemented on a 4-yr cycle. This is a rapid, site-level assessment tool adapted from the World Bank and World Wildlife Fund's system, supplemented by annual personal performance evaluations, to monitor and improve management.

\section{Tools for implementing the BioNet plan Spatial planning}

The latest Cape Town Spatial Development Framework, finalized in April 2011, and eight district Spatial Development Plans and accompanying Environmental Management Frameworks have incorporated the BioNet plan and have thus laid the foundation for future conservation implementation action. City policies such as the draft Coastal Protection Zone and Floodplain River Management limit planned development to areas not vulnerable to storm surge and flooding events, respectively, and thus support biodiversity conservation in such areas. There remain some conflicts between CBAs and proposed new developments in the spatial plans, but the process has ensured engagement of all stakeholders, including politicians, government officials, land owners, and local citizens. Conflicts are particularly intense in the False Bay strandveld vegetation areas in the southeast of the city; with key stakeholders, a collaborative conservation implementation plan for the vegetation type has been produced that prioritizes the most important CBAs that are least likely to conflict with other land uses.

The BioNet plan is recognized by the national and provincial conservation and environmental sectors and is used to inform environmental and land-use decision making at all government levels. It has been incorporated into the Western Cape Biodiversity Framework, which integrates most biodiversity planning products for the CFR and highlights important biodiversity features that straddle municipal boundaries. The BioNet plan is indispensable in prioritizing sites for implementation in the City's Local Biodiversity Implementation Plan, including collaborative implementation projects with CapeNature.

\section{Communication, education, and public awareness}

Communication, education, and public awareness (CEPA) is an important tool, as conservation implementation is a transdisciplinary process. The $\mathrm{BMB}$ has produced a communications strategy to guide activities, which includes environmental education programs on reserves, workshops for teachers, and templates for articles and interviews in the media. The city belongs to regional and international initiatives that promote awareness of biodiversity issues: namely, Cape Action for People and the Environment (C.A.P.E.) and Local Action for Biodiversity (LAB), respectively. LAB is a program of Local Governments for Sustainability (ICLEI: http://www.iclei.org) in which biodiversity-related CEPA projects are being reviewed to improve their effectiveness for supporting implementation. City reserves are used extensively by schools (38,000 person-days of education in the 2010-2011 financial year). Linked to public awareness, many volunteer groups assist with management activities on reserves: onethird of the work in City-run reserves is accomplished by volunteers. Conservation biology academics also can play a role in publicizing and leading local biodiversity conservation actions (Arlettaz et al. 2010).

\section{Conservation stewardship}

Conservation stewardship is a process whereby landowners secure their land for biodiversity in perpetuity while retaining ownership in return for benefits such as tax rebates and management advice. The BioNet Stewardship Project is a 3yr partnership initiative implemented by the Wilderness Foundation, with the City, Cape West Coast Biosphere Reserve, and provincial and national conservation agencies, to explore the potential of stewardship in the city. South Africa is a world leader in conservation stewardship, and this project follows CapeNature's successful model. The first landowner under this project has signed, and three others with CBA land are in the process of signing, indicating good potential for this implementation tool. Although this tool is more cost-effective than acquisition, it still requires resourcing to employ staff to liaise with landowners, give advice, and carry out regular audits to ensure compliance with management plans. It is therefore a concern that the national government has cut conservation funding to the provinces, as this will reduce landowner support and halt work to negotiate new conservation stewardship sites.

\section{Securing BioNet plan land in public ownership}

The City owns CBA land managed by other nonconservation departments (e.g., City Parks and Bulk Water), and an assessment has been done of the protection status required for these sites using CapeNature's stewardship process. For the most critical sites, the BMB has assumed management; for the others, the current departments will manage based on an approved management plan. Additional areas of the BioNet plan are owned by provincial and national government. Negotiations are underway to secure these areas for biodiversity conservation and look promising for areas not in conflict for housing.

\section{Acquiring land into public ownership}

Where the implementation tools above are inappropriate, purchase of the land should be considered. Unfortunately, the City has no biodiversity conservation land acquisition fund, so this tool cannot be used by officials. There are examples of reactive stewardship, whereby environmental authorization is linked to mitigation for impacts of a development on biodiversity. These reactive measures can include off-site or on-site biodiversity offsets and land swaps in mitigation of enhanced development rights. In many instances, pragmatic decision making can result in greater gains for conservation than the option of no development, provided that a mechanism 
to manage the conservation areas is included in the authorization.

\section{CONCLUSION}

Cape Town is a local biodiversity hotspot within the CFR and should be a regional and national priority for conservation implementation. To the contrary, national government has cut budgets to provinces for biodiversity conservation initiatives and has not prioritized any city biodiversity areas for the NPAES. The problem of a lack of implementation is two-fold. First, national government has not adequately funded the policy tools developed to realize international obligations in reducing biodiversity loss. Second, local government has not been recognized as an important implementation partner. A further problem is created by conflicting policies such as the national housing policy, which aims to provide people with formal housing, but with insufficient funds to minimize the development footprint and loss of CBAs. Meanwhile, development pressures in Cape Town are intensifying, and the opportunity to secure the unique and irreplaceable biodiversity will soon be lost.

Despite the challenges, the City's BMB has implemented a range of innovative measures to improve biodiversity conservation in existing reserves and to secure other areas of the BioNet plan for conservation. Strong collaboration with provincial and national conservation partners has been essential in implementing these measures. Good spatial planning, specifically the production of a systematic biodiversity plan that is incorporated into spatial development plans, has been essential in minimizing conflicts with urban development and in prioritizing sites for conservation implementation. Unfortunately, conflicts cannot be avoided altogether because of the uniqueness of some CBAs within the urban edge.

The importance of retaining natural open space within the urban matrix for the provision of various essential ecosystem services and socioeconomic well-being is currently undervalued and is an aspect that needs to be communicated more strongly to City decision makers in support of biodiversity conservation objectives. The new stewardship project to secure biodiversity on public land and explore conservation stewardship on private land is showing good promise but will require additional funding beyond the current 3 -yr grant to follow through to its full potential. A lack of resources hampers alternative actions to secure sites not amenable to stewardship, although some resources may be unlocked through the environmental impact assessment process in mitigation for enhanced development rights.

Can Cape Town's unique biodiversity be saved? Although there is a clear understanding of the biodiversity conservation priorities and some implementation headway is being made, stronger political commitment at national, provincial, and local levels is needed to fund implementation. Owing to the city's high population growth rate, the timeframe is short, about 9 yr before all options are unfeasible; therefore, successful implementation of the full BioNet plan is unlikely unless national or international funding can be sourced.

Responses to this article can be read online at: http://www.ecologyandsociety.org/voll7/iss2/art28/ responses/

\section{Acknowledgments:}

Thanks are due to Amalia Stipinovich for the updated BioNet plan statistics. This paper is a product of the Urban Ecology CityLab, which is part of the CityLab program of the African Centre for Cities at the University of Cape Town. The African Centre for Cities' CityLab program is funded through the Mistra Urban Futures network (which is funded by Mistra, the Foundation for Strategic Environmental Research, and the Swedish International Development Cooperation Agency), the Provincial Government of the Western Cape (Department of Human Settlements), and the City of Cape Town.

\section{LITERATURE CITED}

Angelstam, P., G. Mikusinski, B.-I. Rönnbäck, A. Östman, M. Lazdinis, J.-M. Roberge, W. Arnberg, and J. Olsson. 2003. Two-dimensional gap analysis: a tool for efficient conservation planning and biodiversity policy implementation. Ambio 32(8):527-534.

Apostolopoulou, E., and J. D. Pantis. 2009. Conceptual gaps in the national strategy for the implementation of the European Natura 2000 conservation policy in Greece. Biological Conservation 142(1):221-237. http://dx.doi.org/10.1016/j.bio con.2008.10.021

Arifin, H. S., and N. Nakagoshi. 2011. Landscape ecology and urban biodiversity in tropical Indonesian cities. Landscape and Ecologcial Engineering 7(1):33-43. http://dx.doi.org/10. 1007/s11355-010-0145-9

Arlettaz, R., M. Schaub, J. Fournier, T. S. Reichlin, A. Sierro, J. E. M. Watson, and V. Braunisch. 2010. From publications to public actions: when conservation biologists bridge the gap between research and implementation. Bioscience 60 (10):835-842. http://dx.doi.org/10.1525/bio.2010.60.10.10

Ashwell, A. 2010. Teens need nature too: programmes, poetry and possibilities in the City of Cape Town. Unpublished report. Parks Victoria, Melbourne, Australia. [online] URL: http://w ww.hphpcentral.com/research/teens-need-nature-too-programmespoetry-and-possibilities-in-the-city-of-cape-town-by-alice-ashwell

Boraine, A., O. Crankshaw, C. Engelbrecht, G. Gotz, S. Mbanga, M. Narsoo, and S. Parnell. 2006. The state of South 
African cities a decade after democracy. Urban Studies 43 (2):259-284. http://dx.doi.org/10.1080/00420980500416990

Barnes, K. N., editor. 2000. The Eskom red data book of birds of South Africa, Lesotho and Swaziland. Birdlife South Africa, Johannesburg, South Africa.

Branch, W. R., editor. 1998. Field guide to snakes and other reptiles of southern Africa. Third edition. Struik, Cape Town, South Africa.

Brown, C., and R. Magoba. 2009. Rivers and wetlands of Cape Town: caring for our rich aquatic heritage. Water Research Commission Report TT376/08. Water Research Commission, Cape Town, South Africa.

Cadman, M., C. Petersen, A. Driver, N. Sekhran, K. Maze, and S. Munzhedzi. 2010. Biodiversity for development: South Africa's landscape approach to conserving biodiversity and promoting ecosystem resilience. South African National Biodiversity Institute, Pretoria, South Africa.

Chivian, E., and A. Bernstein, editors. 2008. Sustaining life: how human health depends on biodiversity. Oxford University Press, New York, New York, USA.

Cowling, R. M., P. M. Holmes, and A. G. Rebelo. 1992. Plant diversity and endemism. Pages 62-112 in R. M. Cowling, editor. The ecology of fynbos: nutrients, fire and diversity. Oxford University Press, Cape Town, South Africa.

Cowling, R. M., A. T. Knight, S. D. J. Privett, and G. Sharma. 2009. Invest in opportunity, not inventory of hotspots. Conservation Biology 24(2):633-635. http://dx.doi.org/10.1111/ j.1523-1739.2009.01342.x

Department of Environmental Affairs and Tourism. 2007. Guideline regarding the determination of bioregions and the preparation and publication of bioregional plans. General Notice 1112 of 2007. Department of Environmental Affairs and Tourism, Pretoria, South Africa.

De Wit, M. P., H. Van Zyl, D. J. Crookes, J. N. Blignaut, T. Jayiya, V. Goiset, and B. K. Mahumani. 2009. Investing in natural assets. A business case for the environment in the City of Cape Town. Report prepared for the City of Cape Town, Cape Town, South Africa.

Driver, A., K. Maze, M. Rouget, A. T. Lombard, J. Nel, J. K. Turpie, R. M. Cowling, P. Desmet, P. Goodman, P. Harris, J. Jonas, B. Reyers, K. Sink, and T. Strauss. 2005. National spatial biodiversity assessment 2004: priorities for biodiversity conservation in South Africa. Strelitzia 17. South African National Biodiversity Institute, Pretoria, South Africa.

Gibbons, P., C. Zammit, K. Youngentob, H. P. Possingham, D. B. Lindenmayer, S. Bekessy, M. Burgman, M. Colyvan, M. Considine, A. Felton, R. J. Hobbs, K. Hurley, C. McAlpine,
M. A. McCarthy, J. Moore, D. Robinson, D. Salt, and B. Wintle. 2008. Some practical suggestions for improving engagement between researchers and policy-makers in natural resource management. Ecological Management and Restoration 9(3):182-186. http://dx.doi.org/10.1111/j.1442-8 903.2008.00416.x

Gill, N., G. Waitt, and L. Head. 2009. Local engagements with urban bushland: moving beyond bounded practice for urban biodiversity management. Landscape and Urban Planning 93 (3-4):184-193. http://dx.doi.org/10.1016/j.landurbplan.2009.07.004

Government of South Africa. 1998. National Environmental Management Act 107 of 1998: 27 November 1998. South African Government Gazette 40(1951):1-72.

Government of South Africa. 2003. National Environmental Management: Protected Areas Act 57 of 2003: 18 February 2004. South African Government Gazette 464(26025):1-50.

Government of South Africa. 2004. National Environmental Management: Biodiversity Act 10 of 2004: 7 June 2004. South African Government Gazette 467(26436):1-84.

Government of South Africa. 2009. Draft national list of threatened ecosystems. Government Gazette Number 32689, 06 November 2009 Part B. Government of South Africa, Pretoria, South Africa.

Government of South Africa. 2010. National protected area expansion strategy for South Africa 2008: Priorities for expanding the protected area network for ecological sustainability and climate change adaptation. Government of South Africa, Pretoria, South Africa.

Hahs, A. K., M. J. McDonnell, M. A. McCarthy, P. A. Vesk, R. T. Corlett, B. A. Norton, S. E. Clemants, R. P. Duncan, K. Thompson, M. W. Schwartz, and N. S. G. Williams. 2009. A global synthesis of plant extinction rates in urban areas. Ecology Letters 12(11):1165-1173. http://dx.doi.org/10.1111/ j.1461-0248.2009.01372.x

Helme, N. A., and T. H. Trinder-Smith. 2006. The endemic flora of the Cape Peninsula, South Africa. South African Journal of Botany 72(2):205-210. http://dx.doi.org/10.1016/j. sajb.2005.07.004

Impson, N. D. 2007. Freshwater fishes. Pages 18-35 in Western Cape province state of biodiversity 2007. CapeNature, Cape Town, South Africa.

Knight, A. T., and R. M. Cowling. 2007. Embracing opportunism in the selection of priority conservation areas. Conservation Biology 21(4):1124-1126. http://dx.doi.org/10. 1111/j.1523-1739.2007.00690.x

Knight, A. T., A. Driver, R. M. Cowling, K. Maze, P. G. Desmet, A. T. Lombard, M. Rouget, M. A. Botha, A. F. Boshoff, J. G. Castley, P. S. Goodman, K. MacKinnon, S. M. 
Pierce, R. Sims-Castley, W. I. Stewart, and A. von Hase. 2006. Designing systematic conservation assessments that promote effective implementation: best practice from South Africa. Conservation Biology 20(3):739-750. http://dx.doi.org/10.1111/ j.1523-1739.2006.00452.x

Knight, A. T., R. M. Cowling, M. Rouget, A. Balmford, A. T. Lombard, and B. M. Campbell. 2008. Knowing but not doing: selecting priority conservation areas and the researchimplementation gap. Conservation Biology 22(3):610-617. http://dx.doi.org/10.1111/j.1523-1739.2008.00914.x

Knight, A. T., R. M. Cowling, A. F. Boshoff, S. L. Wilson, and S. M. Pierce. 2011. Walking STEP: lessons for linking spatial prioritisations to implementation strategies. Biological Conservation 144(1):202-211. http://dx.doi.org/10.1016/j.bio con.2010.08.017

Maree, K. S., and D. C. Vromans. 2010. The biodiversity sector plan for the Saldanha Bay, Bergrivier, Cederberg and Matzikama municipalities. CapeNature, Kirstenbosch, South Africa.

Margules, C. R., and R. L. Pressey. 2000. Systematic conservation planning. Nature 405:243-253. http://dx.doi.org $\underline{110.1038 / 35012251}$

McKinney, M. L. 2006. Urbanization as a major cause of biotic homogenization. Biological Conservation 127(3):247-260. http://dx.doi.org/10.1016/j.biocon.2005.09.005

Midgley, G. F., L. Hannah, D. Millar, M. C. Rutherford, and L. W. Powrie. 2002. Assessing the vulnerability of species richness to anthropogenic climate change in a biodiversity hotspot. Global Ecology and Biogeography 11(6):445-451. http://dx.doi.org/10.1046/j.1466-822X.2002.00307.x

Minter, L. R., M. Burger, J. A. Harrison, H. H. Braack, P. J. Bishop, and D. Kloepfer, editors. 2004. Atlas and Red Data Book of the frogs of South Africa, Lesotho and Swaziland. Smithsonian Institution, Washington, D.C., USA.

Mucina, L., M. C. Rutherford, and L. Powrie, editors. 2006. Vegetation map of South Africa, Lesotho and Swaziland: shapefiles of basic mapping units. Beta version 4.0. February 2004. South African National Botanical Institute, Cape Town, South Africa.

Myers, N., R. A. Mittermeier, C. G. Mittermeier, G. A. B. da Fonseca, and J. Kent. 2000. Biodiversity hotspots for conservation priorities. Nature 403:853-858. http://dx.doi.org $\underline{110.1038 / 35002501}$

Pauw, A., and K. Louw. 2012. Urbanization drives a reduction in functional diversity in a guild of nectar-feeding birds. Ecology and Society 17(2): 27. http://dx.doi.org/10.5751/ES04758-170227
Petersen, L. M., E. J. Moll, R. Collins, and M. T. Hockings. 2012. Development of a compendium of local, wild-harvested species used in the informal economy trade, Cape Town, South Africa. Ecology and Society 17(2): 26. http://dx.doi.org/10.5 751/ES-04537-170226

Picker, M. D., and M. J. Samways. 1996. Faunal diversity and endemicity of the Cape Peninsula, South Africa: a first assessment. Biodiversity and Conservation 5(5):591-606. htt p://dx.doi.org/10.1007/BF00137611

Raimondo, D., L. Von Staden, W. Foden, J. E. Victor, N. A. Helme, R. C. Turner, D. A. Kamundi, and P. A. Manyama, editors. 2009. Red List of South African plants. Strelitzia 25. South African National Biodiversity Institute, Pretoria, South Africa.

Rebelo, A. G. 1992. Preservation of biotic diversity. Pages 309-344 in R. M. Cowling, editor. The ecology of fynbos: nutrients, fire and diversity. Oxford University Press, Cape Town, South Africa.

Rebelo, A. G., C. Boucher, N. A. Helme, L. Mucina, and M. C. Rutherford. 2006. In Fynbos biome: the vegetation of South Africa, Lesotho and Swaziland. L. Mucina and M. C. Rutherford, editors. Strelitzia 19. South African National Biodiversity Institute, Pretoria, South Africa.

Rebelo, A. G., P. M. Holmes, C. Dorse, and J. Wood. 2011. Impacts of urbanization in a biodiversity hotspot: conservation challenges in Metropolitan Cape Town. South African Journal of Botany 77(1):20-35. http://dx.doi.org/10.1016/j.sajb.2010. $\underline{04.006}$

Richardson, D. M. and B. W. van Wilgen. 2004. Invasive alien plants in South Africa: How well do we understand the ecological impacts? South African Journal of Science 100:45-52.

Rouget, M., B. Reyers, Z. Jonas, P. Desmet, A. Driver, K. Maze, B. Egoh, and R. M. Cowling. 2004. South African national spatial biodiversity assessment 2004: technical report. Volume 1: terrestrial component. South African National Biodiversity Institute, Pretoria, South Africa.

Roux, D. J., K. H. Rogers, H. C. Biggs, P. J. Ashton, and S. Sergeant. 2006. Bridging the science-management divide: moving from unidirectional knowledge transfer to knowledge interfacing and sharing. Ecology and Society 11(1): 4. [online] URL: http://www.ecologyandsociety.org/vol11/iss1/art4/.

Roux, D. J., P. J. Ashton, J. L. Nel, and H. M. MacKay. 2008. Improving cross-setor policy integration and cooperation in support of freshwater conservation. Conservation Biology 22 (6):1382-1387. http://dx.doi.org/http://dx.doi.org/10.1111/j.1 523-1739.2008.01080.x 
Ryder, D. S., M. Tomlinson, B. Gawne, and G. E. Likens. 2010. Defining and using 'best available science': a policy conundrum for the management of aquatic ecosystems. Marine and Freshwater Research 61(7):821-828 http://dx.doi. org/http://dx.doi.org/10.1071/MF10113

Sandström, U. G., P. Angelstam, and A. Khakee. 2006. Urban comprehensive planning - identifying barriers for the maintenance of functional habitat networks. Landscape and Urban Planning 75(1-2):43-57. http://dx.doi.org/10.1016/j.la ndurbplan.2004.11.016

Simmons, M. T., and R. M. Cowling. 1996. Why is the Cape Peninsula so rich in plant species? An analysis of the independent diversity components. Biodiversity and Conservation 5(5):551-573. http://dx.doi.org/10.1007/BF001 $\underline{37609}$

Turpie, J. K., B. J. Heydenrych, and S. J. Lamberth. 2003. Economic value of terrestrial and marine biodiversity in the Cape Floristic Region: implications for defining effective and socially optimal conservation strategies. Biological Conservation 112(1-2):233-251. http://dx.doi.org/10.1016/S0 006-3207(02)00398-1

Tweddle, D., R. Bills, E. Swartz, W. Coetzer, L. Da Costa, J. Engelbrecht, J. Cambray, B. Marshall, D. Impson, P. H. Skelton, W. R. T. Darwall, and K. S. Smith. 2009. The status and distribution of freshwater fishes. Pages 21-36 in R. T. Darwall, W. K. G. Smith, D. Tweddle, and P. Skelton, editors. The status and distribution of freshwater biodiversity in southern Africa. IUCN, Gland, Switzerland, and South African Institute for Aquatic Biodiversity, Grahamstown, South Africa.

Underwood, E. C., J. H. Viers, K. R. Klausmeyer, R. L. Cox, and M. R. Shaw. 2009. Threats and biodiversity in the Mediterranean biome. Diversity and Distributions 15 (2):188-197. http://dx.doi.org/10.1111/j.1472-4642.2008.00518. $\underline{\mathrm{X}}$

Wood, J., A. B. Low, J. S. Donaldson, and A. G. Rebelo. 1994. Threats to plant species diversity through urbanization and habitat fragmentation in the Cape Metropolitan area, South Africa. Pages 259-274 in B. J. Huntley, editor. Botanical diversity in southern Africa. Strelitzia 1. South African National Biodiversity Institute, Pretoria, South Africa. 